\title{
Waste wood as bioenergy feedstock. Climate change impacts and related emission uncertainties from waste wood based energy systems in the UK
}

DOI:

10.1016/j.wasman.2017.11.042

\section{Document Version \\ Accepted author manuscript}

Link to publication record in Manchester Research Explorer

Citation for published version (APA):

Röder, M., \& Thornley, P. (2017). Waste wood as bioenergy feedstock. Climate change impacts and related emission uncertainties from waste wood based energy systems in the UK. Waste Management.

https://doi.org/10.1016/j.wasman.2017.11.042

\section{Published in:}

Waste Management

\section{Citing this paper}

Please note that where the full-text provided on Manchester Research Explorer is the Author Accepted Manuscript or Proof version this may differ from the final Published version. If citing, it is advised that you check and use the publisher's definitive version.

\section{General rights}

Copyright and moral rights for the publications made accessible in the Research Explorer are retained by the authors and/or other copyright owners and it is a condition of accessing publications that users recognise and abide by the legal requirements associated with these rights.

\section{Takedown policy}

If you believe that this document breaches copyright please refer to the University of Manchester's Takedown Procedures [http://man.ac.uk/04Y6Bo] or contact uml.scholarlycommunications@manchester.ac.uk providing relevant details, so we can investigate your claim.

\section{OPEN ACCESS}


1 Waste wood as bioenergy feedstock. Climate change impacts and related emission uncertainties from waste

2 wood based energy systems in the UK

3 Mirjam Röder ${ }^{\mathrm{a},{ }^{*}}$ mirjam.roeder@manchester.ac.uk,

4

Patricia Thornley ${ }^{\mathrm{P}}$.Thornley@manchester.ac.uk

$5 \quad{ }^{a}$ Tyndall Centre for Climate Change Research, The University of Manchester, Oxford Road, Manchester M13

6 9PL, United Kingdom

$7 \quad{ }^{*}$ Corresponding author: Mirjam Röder, Tyndall Centre for Climate Change Research, Oxford Road, Manchester

$8 \quad$ M13 9PL, United Kingdom mirjam.roeder@manchester.ac.uk, Tel. +44 (0)161 2754344

9

10 Keywords: bioenergy, waste wood, greenhouse gases (GHG), life cycle assessment, emission uncertainties,

11 climate change 
The current UK bioenergy sector is dominated by large imports of biomass feedstocks and the UK is the biggest importer of wood pellets globally (FAO, 2016) to produce bioelectricity. Research by others showed that the UK could provide large amounts of bioenergy feedstocks nationally when utilising wastes and residues (Welfle et al., 2014). Waste wood, especially lower grades are one of these untapped resources. Considering the urgent need to shift to low carbon energy carriers, lower grade waste wood could provide an alternative energy feedstock and at the same time reduce emissions from landfill and support waste management in general. It would also be a feedstock with an existing infrastructure, which fits existing technologies and could possibly contribute to UK climate change targets in a timely manner.

While there has been various research on the thermochemical and conversion characteristics of treated waste wood (Edo et al., 2016; Enestam et al., 2013; Gori et al., 2013; Hwang et al., 2014; Yorulmaz and Atimtay, 2009), not much work has been done on the emission reduction potential of treated waste wood. Studies assessing the climate mitigation potential of waste wood usually focus on untreated feedstocks that do not fall under the Waste Incineration Directive (WDI) (Gomez-Barea et al., 2010; McManus, 2010; Sheth and Babu, 2010; Vanneste et al., 2011) and have therefore very similar properties to virgin wood or residues from sawmills. With this climate change impacts related to contaminates and chemicals from wood treatment are often not taken into account when investigating bioenergy feedstocks and the emission reduction potential of lower grade feedstocks. Therefore, this research assesses feedstocks that might be considered for energy generation as part of energy from waste systems but not necessarily as bioenergy options to reduce emissions to support climate change targets.

According to latest estimates about 4.3 million tonnes of waste wood are produced in the UK annually (Defra, 2012b). These estimates are vague and over the last ten years they varied between 4.1 to 10.5 million tonnes (Defra, 2008, 2012a, b; Pöyry, 2009; Tolvik, 2011). This is due to waste wood being sometimes difficult to recycle, collect and separate from mixed waste. Moreover, wood processing and wood using sectors such as construction, furniture and joinery are sensitive to economic changes and the amounts of arising waste wood can therefore vary from year to year (Defra, 2008, 2012b; Greenhalf and Brown, 2012; Letsrecycle, 2015; 
fate of the waste wood is not always clear. Estimates from the industry suggest that 1 to 2 million tonnes of

waste wood per year are available for bioenergy applications.

\section{Table 1 Waste wood grades in the UK (WRAP, 2012)}

Grade A: clean untreated waste wood (hardwood and softwood) in form of, e.g., process off-cuts, packaging, pallets or cable drums,

Grade B: mixed grade (hardwood and softwood), up to $60 \%$ grade A wood mixed with wood containing contaminants like paint and screws at a low proportion. Can contain up to $5 \%$ to $10 \%$ panel products but no lower grade material; WID compliant if operator cannot demonstrate that no grade $\mathrm{C}$ is included,

Grade C: fuel grade, treated wood, e.g., coated, painted and impregnated products, high content panel products, chipboards, MDF, plywood, fibreboard; WID compliant,

Grade D: low grade and hazardous waste wood, chipboard, processed and treated wood containing contaminants such as melamine, arsenic, chromium and creosote, e.g., railway sleepers, transmission poles; hazardous waste incinerator.
54
The following research presents the result of a lifecycle assessment (LCA) of energy generation from different waste wood grades at different scale and applications, with existing technologies, infrastructures and 
57 regulations in the UK. While the type of combustion system has an impact on the operational and environmental performance, the focus was on the most common systems used in the UK.

59 The objective was to evaluate the climate change impacts and related emission uncertainties of waste wood based energy in the UK and discuss its potential, barriers and opportunities as a valid bioenergy feedstock.

\section{Methods}

\subsection{Lifecycle assessment}

As methodology attributional lifecycle assessment (LCA) has been applied according to ISO Standard 14040:2006 and 14044:2006 (BSI, 2006a, b). The goal of this LCA was to investigate climate change impacts and emission uncertainties of different options to generate energy from different grades of waste wood. This allowed identifying the supply chain processes and feedstock properties making major emission contributions. The impact category presented in this paper is global warming potential (GWP). The calculations were done with the LCA software SimaPro 8.3 using the Ecoinvent database and the ILCD 2011 Midpoint+V1.09 method (PRé, 2016). Additional calculations and the system modelling identifying feedstock demands and analysing key factors were done in Excel and in BEAT2 V2.1 (Defra, 2010). BEAT2 V2.1 is a tool providing information on environmental impacts of UK bioenergy systems. The results account for greenhouse gases expressed as $\mathrm{CO}_{2} \mathrm{eq}$ with a 100-year time horizon with emission factors used in the selected methods in SimaPro and BEAT2 V2.1. Biogenic carbon has not been included in the assessment due to lacking data about the lifetime and origin of the waste wood and in accordance with current accounting frameworks in the UK and the EU.

The reference scenarios include a variety of different fuels (including landfill gas and waste incineration with energy recovery) that reflect the current UK energy system at commensurate scales. The details for the different waste wood systems and their reference scenarios are presented in Table 1 . The supply chains selected include mature and existing technologies in accordance with specifications and regulations for handling, processing and recycling waste in the United Kingdom (Defra, 2008, 2011; EA, 2013; WRAP, 2012). Less mature technologies such as gasification and pyrolysis may be possible in future but the research aims to investigate existing technologies, which are readily available to support the UK's climate change targets in a timely manner, and the alternatives are not yet adequately proven. 
The scope of analysis is energy from waste wood supply chains within the UK, including all transportation, handling and processing steps of the supply chain starting with the collection and delivery of the waste wood to the waste or processing yard, handling, processing of the waste wood, transport of the feedstock to the bioenergy facility and energy conversion in different configurations as presented in Figure 1 and Table 2Fable 1. The functional unit (FU) was $1 \mathrm{MWh}$ of generated energy in form of electricity, heat and combined heat and power (CHP). The final unit of measurement was $\mathrm{kg} \mathrm{CO}_{2}$ equivalent (eq) $\mathrm{MWh}^{-1}$. As this research investigated waste products, the energy demand and emissions included in the calculation start with the end of life of the original product, hence the collection of the product for disposal or recycling. Any upstream inputs and emissions related to the production of the original product were excluded from the analysis. The investigated options included different grades of waste wood, which are used in different applications with different supply chain processes in accordance with existing legislation for waste handling and processing (Defra, 2011; WRAP, 2012).

The following waste wood grades, from industrial and post-consumer use, are considered as feedstocks in this research were:

- Grade A as clean waste wood not falling under the WID regulations and suitable for domestic application and compliant with renewable energy support schemes. Feedstock is considered as pellets and chips for domestic and commercial applications;

- Grade B with a maximum of $10 \%$ panel products in the fuel mix, with adequate control of the fuel mix no WID compliance required and compliant with renewable energy support schemes. Feedstock is considered as chips for commercial applications;

- Lower grade mix of grades $C$ and $D$, containing grade $C$ feedstocks and higher contaminated waste wood such as melamine containing panelboard, CCA (chromated copper arsenate) treated wood, requires WID compliance and not compliant with renewable energy support schemes. Feedstock is considered as chips for commercial applications. Grade C and D are considered as mixed fuel as a separation into the different grades is often difficult and not cost-effective. 
The feedstock demand is based on the unit of energy produced, the efficiency of the furnace/boiler, the calorific value of the feedstock. As there are changes in feedstocks characteristics and material losses along the supply chain, the demand of unprocessed biomass has also been considered. The values are provided in SubT1.

The sectoral competition for resource can influence environmental impacts of waste wood as bioenergy feedstock if other sectors have to divert supply chains. Especially, grade A and B are currently also used in the wood processing industry and using this feedstock for energy could lead to a shift to using more virgin wood in the wood processing industry (Defra, 2012a; Mitchell and Stevens, 2008). Evaluating the emission impact of using grade A for energy instead of the wood processing industry has been done by others (Defra, 2012a; Mitchell and Stevens, 2008) and was not within the scope of the here presented analysis. Compared to this grades $C$ and $D$ are resources available for energy generation without shifting resources away from other sectors apart from landfill or energy recovery (Defra, 2012a, b; Greenhalf and Brown, 2012; Jambeck et al., 2007). Nevertheless, grade A and B are also feedstocks in bioenergy facilities, which do not fall under the WID..

\begin{tabular}{|c|c|c|c|c|c|}
\hline & $\begin{array}{l}\text { Feedstock } \\
\text { type }\end{array}$ & Application & $\begin{array}{l}\text { Scale and } \\
\text { technology }\end{array}$ & $\begin{array}{l}\text { Reference } \\
\text { scenario }\end{array}$ & Rationale for selection \\
\hline 1 & $\begin{array}{l}\text { Grade A, } \\
\text { Chips }\end{array}$ & $\mathrm{CHP}$ & $\begin{array}{l}\text { Medium scale } \\
\text { (fluidised } \\
\text { bed) }\end{array}$ & $\begin{array}{l}\text { Oil, natural } \\
\text { gas }\end{array}$ & $\begin{array}{l}\text { Community CHP facility (for district } \\
\text { heating and electricity provision) } \\
\text { common in European countries }\end{array}$ \\
\hline 2 & $\begin{array}{l}\text { Grade A, } \\
\text { Pellets }\end{array}$ & $\mathrm{CHP}$ & $\begin{array}{l}\text { Medium scale } \\
\text { (fluidised } \\
\text { bed) }\end{array}$ & $\begin{array}{l}\text { Oil, natural } \\
\text { gas }\end{array}$ & Similar to CHP facility in Chilton, UK \\
\hline 3 & $\begin{array}{l}\text { Grade B, } \\
\text { Chips }\end{array}$ & $\mathrm{CHP}$ & $\begin{array}{l}\text { Large scale } \\
\text { (fluidised } \\
\text { bed) }\end{array}$ & $\begin{array}{l}\text { Oil, natural } \\
\text { gas }\end{array}$ & $\begin{array}{l}\text { Commercial CHP facility for } \\
\text { generating heating and electricity }\end{array}$ \\
\hline
\end{tabular}




\begin{tabular}{|c|c|c|c|c|c|}
\hline 4 & $\begin{array}{l}\text { Grade C-D, } \\
\text { Chips }\end{array}$ & $\mathrm{CHP}$ & $\begin{array}{l}\text { Large scale } \\
\text { (fluidised } \\
\text { bed) }\end{array}$ & $\begin{array}{l}\text { Oil, natural } \\
\text { gas }\end{array}$ & $\begin{array}{l}\text { Incineration of waste wood and } \\
\text { potentially other wastes providing } \\
\text { heat and electricity (WID compliant) }\end{array}$ \\
\hline 5 & $\begin{array}{l}\text { Grade A, } \\
\text { Chips }\end{array}$ & Electricity & $\begin{array}{l}\text { Medium scale } \\
\text { (fluidised } \\
\text { bed) }\end{array}$ & $\begin{array}{l}\text { Coal, natural } \\
\text { gas }\end{array}$ & Similar to CHP facility in Chilton, UK \\
\hline 6 & $\begin{array}{l}\text { Grade A, } \\
\text { Pellets }\end{array}$ & Electricity & $\begin{array}{l}\text { Large scale } \\
\text { (pulverised fuel } \\
\text { combustion) }\end{array}$ & $\begin{array}{l}\text { Coal, natural } \\
\text { gas }\end{array}$ & $\begin{array}{l}\text { Similar to planned facilities in } \\
\text { Rotherham and Port Clarence, UK }\end{array}$ \\
\hline 7 & $\begin{array}{l}\text { Grade B, } \\
\text { Chips }\end{array}$ & Electricity & $\begin{array}{l}\text { Large scale } \\
\text { (fluidised bed) }\end{array}$ & $\begin{array}{l}\text { Coal, natural } \\
\text { gas }\end{array}$ & $\begin{array}{l}\text { Similar to planned facilities in } \\
\text { Rotherham and Port Clarence, UK }\end{array}$ \\
\hline 8 & $\begin{array}{l}\text { Grade C-D, } \\
\text { Chips }\end{array}$ & Electricity & $\begin{array}{l}\text { Large scale (moving } \\
\text { grate } \\
\text { technology) }\end{array}$ & $\begin{array}{l}\text { Coal, natural } \\
\text { gas, landfill } \\
\text { gas and waste } \\
\text { incineration } \\
\text { with energy } \\
\text { recovery }\end{array}$ & $\begin{array}{l}\text { Incineration facility providing } \\
\text { electricity (WID compliant) }\end{array}$ \\
\hline 9 & $\begin{array}{l}\text { Grade A, } \\
\text { Chips }\end{array}$ & Heat & $\begin{array}{l}\text { Domestic scale } \\
\text { (biomass boiler) }\end{array}$ & $\begin{array}{l}\text { Oil, natural } \\
\text { gas }\end{array}$ & Domestic chip boiler \\
\hline 10 & $\begin{array}{l}\text { Grade A, } \\
\text { Pellets }\end{array}$ & Heat & $\begin{array}{l}\text { Domestic scale } \\
\text { (biomass boiler) }\end{array}$ & $\begin{array}{l}\text { Oil, natural } \\
\text { gas }\end{array}$ & Domestic pellet boiler \\
\hline 11 & $\begin{array}{l}\text { Grade B, } \\
\text { Chips }\end{array}$ & Heat & $\begin{array}{l}\text { Medium scale (step } \\
\text { grate) }\end{array}$ & $\begin{array}{l}\text { Oil, natural } \\
\text { gas }\end{array}$ & $\begin{array}{l}\text { Commercial facility providing heat } \\
\text { (WID compliant) }\end{array}$ \\
\hline 12 & $\begin{array}{l}\text { Grade C-D, } \\
\text { Chips }\end{array}$ & Heat & $\begin{array}{l}\text { Large scale (moving } \\
\text { grate } \\
\text { technology) }\end{array}$ & $\begin{array}{l}\text { Oil, natural } \\
\text { gas }\end{array}$ & $\begin{array}{l}\text { Incineration facility providing heat } \\
\text { (WID compliant) }\end{array}$ \\
\hline
\end{tabular}


One of the goals of this research was to identify emission uncertainties of the different waste wood options.

For this, the parameters with the most significant emission impact were varied to establish to which extent the different options deliver emission reductions. For each waste wood option, a baseline case was evaluated and then variations to different supply chain factors applied.

Transport fuel use

Transport was identified as one of the three main contributors to the emissions from energy from waste wood (Figure 2). Data for fuel consumption varies widely between data provided by vehicle manufacturers, real life fuel use and values given and used in research. Truck engines, loads, driving behaviour and conditions can all have an impact on the real life fuel use and lead to variations (ICCT, 2015; Muncrief, 2015). Provided values for average roundtrip fuel use per $100 \mathrm{~km}$ of articulated haulage vehicles vary between 25 litres (Volvo, 2015) and 43 litres (DfT, 2014). For the European Union it is expected that a 40\% to 50\% fuel use reduction to 19 to 22 litres per $100 \mathrm{~km}$ is possible by 2026 due to efficiency achievements (Delgado and Lutsey, 2015).

Considering the range of values and variations in fuel use (Cristea et al., 2013; Delgado and Lutsey, 2015; DfT, 2014; Ecoinvent, 2016; EEA, 2013; Hamelinck et al., 2005; ICCT, 2015; Jonker et al., 2013; Muncrief and Sharp, 2015; Volvo, 2015; VTT, 2013), a default value of 36 litres per $100 \mathrm{~km}$ as roundtrip with empty return has been assumed. To test the sensitivity of transport emissions, fuel use has been increased to 43 litres per $100 \mathrm{~km}$ and reduced to 22 litres per $100 \mathrm{~km}$ to test changes to the overall supply chain emissions.

\section{Wood processing}

It is common practice that the waste wood is processed in outdoor processing facilities by diesel-powered machinery. Processing waste wood in buildings or covered facilities could reduce noise and dust pollution for the neighbourhood. This would require processing facilities powered by electricity. To compare the environmental impact of the different fuel uses, outdoor processing with diesel and indoor processing with electricity has been compared. 
In the case of pelletized feedstocks, the pelletizing process contributes significantly to the overall emission profile (Figure 2). Data on the electricity requirement for the pelletizing process varies in the literature from 63 to 250 kWh for 1 tonne of pellets (Damen and Faaij, 2006; EUBIA, 2016; Fantozzi and Buratti, 2010; Jonker et al., 2013; McKechnie et al., 2010; Thek and Obernberger, 2004). This includes processes like reception, crushing, grinding, cooling, packing and storing the feedstock, but does not include the heat required for drying. In case of waste wood, pellet mills reported that drying is not necessarily required as the feedstock has usually a moisture content of less than $20 \%$ and through the heat developed during processing no further drying is required. As a default $160 \mathrm{kWh}$ have been assumed to produce 1 tonne of pellets, as this appeared closest to the most commonly used values. The full range of reported literature values (from $63 \mathrm{kWh}$ to 250 $\mathrm{kWh}$ ) has been tested to evaluate sensitivity to the uncertainty in available data.

Wood is considered to offer advantages over fossil fuels in terms of emissions savings as the timeframe of $\mathrm{CO}_{2}$ sequestration and release is much shorter (Röder and Thornley, 2016) and with a lower sulphur and nitrogen content compared to coal, $\mathrm{SO}_{x}$ and $\mathrm{NO}_{x}$ emissions will also be lower as discussed by others (Lavric et al., 2004; Mitchell et al., 2016). The focus of this analysis will be on the nitrogen content of some waste wood that is much higher due to the presence of urea formaldehyde and urea melamine resins, which can lead to the formation of $\mathrm{N}_{2} \mathrm{O}$ when the waste wood is burned (Khalfi et al., 2000; Liu et al., 2013; Skoglund et al., 2016; Wilen et al., 2007). The fraction of urea resin (UR) in MDF and chipboard varies between $2 \%$ to $13.5 \%$ (WPIF, 2014b) and 6\% to $8 \%$ (WPIF, 2014a) respectively. As the formation of $\mathrm{N}_{2} \mathrm{O}$ can have a major impact on the overall emission profile, illustrated as the conversion category in Figure 2, sensitivities to the UR fraction were tested.

170 For the grade B fuel mix a panelboard content of $5 \%$ to $10 \%$ is possible to still be considered under renewable

171 energy support schemes, but to determine the exact composition of the mix is difficult and not always consistent. A fuel mix with $10 \%$ panelboard has been considered as baseline. For the sensitivity analysis, the overall content of panelboard in the fuel mix has been reduced to $5 \%$. 
Reported scientific results on the $\mathrm{N}_{2} \mathrm{O}$ formation during combustion are lacking. The BEAT2 model (Defra,

2010) assumes as a default that $10 \%$ of the UR converts to $\mathrm{N}_{2} \mathrm{O}$, which has been considered for the here presented calculations. To test the sensitivity of this factor the value for $\mathrm{N}_{2} \mathrm{O}$ formation during combustion has been decreased and increased to $5 \%$ and $15 \%$ for the grade B baseline option. $\pm 10 \%$ to evaluate how variations in the feedstock characteristics impact on the supply chain emission profile.

Table 3 Sensitivity analysis; Parameter variations for tested factors

\begin{tabular}{|l|l|l|l|}
\hline Factor & Default & Variation 1 & Variation 2 \\
\hline Transport fuel & $0.36 \mathrm{I} / \mathrm{km}$ & $0.43 \mathrm{I} / \mathrm{km}$ & $0.22 \mathrm{I} / \mathrm{km}$ \\
\hline Wood processing & diesel & electricity & $\mathrm{n} / \mathrm{a}$ \\
\hline Pelletizing electricity demand & $160 \mathrm{kWh} / \mathrm{t}$ & $250 \mathrm{kWh} / \mathrm{t}$ & $63 \mathrm{kWh} / \mathrm{t}$ \\
\hline N2O formation & $10 \%$ & $15 \%$ & $5 \%$ \\
\hline Grade B panelboard content & $10 \%$ & $5 \%$ & $\mathrm{n} / \mathrm{a}$ \\
\hline
\end{tabular}

181

The inventory data for the supply chain processes within the system boundaries was converted to the functional unit of $1 \mathrm{MWh}$ to generate heat and/or electricity. The relevant data for the characteristics of the feedstocks, fuel use for transport, handling and processing and specifications for the energy conversion facility is provided in SubT 1. These have been gathered from appropriate literature sources and reviewed with industrial partners to verify their applicability to practical bioenergy systems. and takes into account losses and moisture content along the supply chain. The demand varies from one waste wood option to the other because of different feedstock characteristics, applied technology and conversion unit specifications (see SubT 1). specialist haulage vehicle used only for biomass transport). 

feedstock is sourced from processed and dry products with moisture contents of $20 \%$ at maximum (Defra, 2012a).

The emissions factors for energy and fuels used for transport and all machine operations for processing were taken from Defra (Defra, 2010, 2016) and Ecoinvent (Ecoinvent, 2016).

In CHP applications either heat or power will usually be the main product but in the absence of more specific information and to facilitate comparison to the other application it has been considered that the heat to power ratio is 4 to 1 with a load factor of $55 \%$. This figure is low for an industrially led heat demand, but is reasonable for provision of space heating and other applications outside the process industries. Previous work has shown that this load factor has a significant impact on life cycle emissions (Thornley et al., 2009), but is largely dictated by local commercial conditions.

\subsection{Emission profiles of baseline options for energy from waste wood}

The emission profiles of the different energy from waste wood options are presented in Figure 2 . This presents the different baseline options based on the numbers provided in SubT 1.

In all options the main share of emissions is related to mainly three categories: transport, feedstock processing and handling and conversion (combustion). Emissions from energy conversion are a major contributor to emissions in all options but in particular for grade B and C-D option. As described in the methods the conversion emissions presented in the graph are gaseous emissions generated during the combustion process and do not relate to the carbon stored in the wood and released as carbon dioxide during combustion. In the options using pellets, emissions related to processing and handling, hence, the electricity used during pelletizing becomes more prominent. The total emissions of the different investigated energy options range between a $\mathrm{CO}_{2}$ eq mass of $53.8 \mathrm{~kg} \mathrm{MWh}$

$218{ }^{1}$ and $814.2 \mathrm{~kg} \mathrm{MWh}^{-1}$. The wide range of the results is mainly related to a) the type of feedstock and b) the different energy conversion configurations. For example, heat from grade A chips has the lowest emission level 
D feedstocks are significantly higher not only because of the higher share of emissions from flue gas but also because of the low efficiency of the applications this type of feedstock can be used in. While grade $A$ feedstocks can be used in highly efficient small and medium scale applications, grade C and D feedstocks can only be used in facilities compliant with the WID (Defra, 2012a), where gas produced during the combustion process must be raised to a temperature of 850 to $1100{ }^{\circ} \mathrm{C}$ for two seconds (Defra, 2011).

Figure 2 Baseline emissions by process contribution from waste wood grade A, B, C-D at different applications $\left(\mathrm{kg} \mathrm{CO} \mathrm{CO}_{2} \mathrm{MWh}^{-1}\right)$

Figure 3 summarises the supply chain emissions of the different waste wood options and the variations based on the results from the sensitivity analysis. The variations (vertical error bars) present the best and the worst case for each energy option. While variations are relatively low for grade A and B chips options, the emission uncertainties are much higher for grade A pellets and grade C-D options. The results of the sensitivity analysis showed that the lowest variations are from changes in transport fuel use. Compared to this, emission variations from using different fuels for wood processing, changing the amount of electricity for pelletizing, varying the amount of panel products in the fuel mix and varying the UR fractions and rate of $\mathrm{N}_{2} \mathrm{O}$ formation in the grade C-D options are more distinct. The single point indicators present the emission level of fossilbased reference scenarios. In cases of larger uncertainties this shows that the emission saving could be significantly diminished if emissions where at the higher end of the uncertainty. Addressing the larger uncertainties would help to understand better at which real emission savings could be achieved. SubT 3 summarises the total emissions of the investigated waste wood options including the results from the sensitivity analysis. The parameters which most significantly reduce or increase the net GHG emission of the system are highlighted and in most cases refers to the parameters that are most prominent in the overall supply chain emissions, e.g., processing emissions for grade A feedstocks, energy conversion emission related to the UR fraction and $\mathrm{N}_{2} \mathrm{O}$ formation for grade $\mathrm{B}$ and C-D feedstocks. The detailed results of the sensitivity analysis are presented in the following sections. 
For all options the same transport distance of $160 \mathrm{~km}$ along the whole supply chain has been considered to make emissions more comparable. The contribution of transport to the total supply chain emission ranges between a $\mathrm{CO}_{2}$ eq mass of $5.5 \mathrm{~kg} \mathrm{MWh}^{-1}$ and $22.2 \mathrm{~kg} \mathrm{MWh}^{-1}$, depending on the energy option (see Figure 4). The variations between the different options refer to the different amounts of feedstock required depending on the form of the feedstock (chips or pellets) and the final application as efficiency and load factor differ between the investigated conversion configuration options (see SubT 1). Fuel efficiency was tested in the sensitivity analysis and the results for an increased fuel use of 43.5 litres per $100 \mathrm{~km}$ and increased fuel use efficiency with 22 litres per $100 \mathrm{~km}$ are presented in the error bars in Figure 4. Changing the transport distance instead of the fuel efficiency would result in similar results. that variations in fuel efficiency have a very low impact on the supply chain and relatively change the total supply chain emissions by a maximum of $1 \%$ (detailed results provided in supplementary material SubT 3 ). efficiency and similar reduced transport distance would make only minor changes to the overall supply chain emissions.

Figure 4 Transport emissions as $\mathrm{kg} \mathrm{CO}_{2} \mathrm{eq} \mathrm{MWh}^{-1}$ with vertical error bars presenting icreased and improved fuel use

Figure 5 shows the results from comparing outdoor diesel-powered and indoor electricity powered wood processing facilities. The grey columns represent the emissions related to the processing with diesel, while the 
vertical error bars show the reduced emission level when processed with electricity. Using electricity-powered processing facilities can reduce the processing and handling emissions by $15 \%$ for pellets and by $27 \%$ for chip feedstock of all grades. The lower emission reductions for pellets are caused by the increased energy demand for the pelletizing process resulting in additional processing emissions compared to the processing of chips. In regards to all energy options, the relative reductions are lowest for grade C-D feedstocks (less than $2 \%$ ) due to the large contribution of other emission categories to the total emission profile. For the other feedstock, also depending on characteristics of the overall emissions relative reductions of $6 \%$ to $11 \%$ can be achieved (detailed results provided in supplementary material SubT 3).

Figure 5 Processing emissions as $\mathrm{kg} \mathrm{CO}_{2} \mathrm{eq} \mathrm{MWh}^{-1}$ with vertical error bars presenting emission reductions

\section{when feedstock is processed with electricity-powered equipment}

The emission impact of varying the electricity demand for the pelletizing process is presented in the first column of Figure 6, showing the emissions from producing 1 tonne of grade A pellets. For the baseline energy requirement a $\mathrm{CO}_{2}$ eq mass of about $169.1 \mathrm{~kg} \mathrm{t}^{-1}$ is released. With the variations of high and low electricity requirements for the pelletizing processes described in the methods and data presented in SubT 1, the emission increase by $32 \%$ to $223.5 \mathrm{~kg} \mathrm{CO}_{2}$ eq $\mathrm{t}^{-1}$ and decrease by $38 \%$ to $104.5 \mathrm{~kg} \mathrm{CO}_{2}$ eq $\mathrm{t}^{-1}$ respectively. presented as error bars grade A pellets for CHP by $19 \%$, for electricity by $23 \%$ and for heat by $17 \%$. Considering lower electricity requirement for pelletizing these supply chain emissions decrease, compared to the baselines, for CHP by $23 \%$, for electricity only by $27 \%$ and for heat only by $20 \%$ (Figure 6 column 2-5, detailed results provided in supplementary material SubT 3). 
299

As shown in Figure 2, emissions related to conversion make a major contribution to grade B and C-D energy options. These emissions are mainly related to the UR fraction and its impacts as described in the methods section. The total amount of emissions related to the conversion process varies between the investigated options due to the different applications and scale. For grade B, 10\% panelboard in the fuel mix was evaluated as the baseline option. Reducing this amount to $5 \%$ lowered the conversion emissions by about $16 \%$ for the CHP options, $25 \%$ for the electricity and $8 \%$ for the heat option (Figure 7).

Considering lower and higher $\mathrm{N}_{2} \mathrm{O}$ formation rates for the grade $\mathrm{B}$ options led to a similar range of variations of the emission level as reducing the amount of panel products in the fuel mix. Assuming that the $\mathrm{N}_{2} \mathrm{O}$ formation rate is $5 \%$ and $15 \%$ (compared to $10 \%$ in the baseline) led to lower and vice versa higher emissions of $\pm 13 \%$ for the CHP options, $\pm 20 \%$ for the electricity option and $\pm 7 \%$ for the heat option (vertical error bars in Figure 7 ).

In all grade C-D options the conversion emissions are extremely dominant. While reduction of the panelboard content in the fuel mix and changes in the $\mathrm{N}_{2} \mathrm{O}$ formation during combustion have been tested for grade $\mathrm{B}$, for the grade C-D options a variation in relation to the UR fraction in the panelboard was analysed. For this, the UR fraction was increased and decreased by $10 \%$ leading to relative variations in the total supply chain emissions of $\pm 8 \%$ to $\pm 9 \%$ (Figure 8 )

With its high global warming potential, $\mathrm{N}_{2} \mathrm{O}$ formed during combustion becomes the most prominent emission component for grade B and C-D options compared to untreated wood and showed the highest sensitivity for grade $b$ and C-D feedstocks.

Figure 7 Conversion emissions as $\mathrm{kg} \mathrm{CO}_{2} \mathrm{eq} \mathrm{MWh}^{-1}$ for grade $\mathrm{B}$ options with a fuel mix of $10 \%$ and $5 \%$ panelboard and variations of the $\mathrm{N}_{2} \mathrm{O}$ formation rate by $\pm 50 \%$ (vertical error bars)

Figure 8 Conversion emissions as $\mathrm{kg} \mathrm{CO}_{2} \mathrm{eq} \mathrm{MWh}^{-1}$ for grade C-D options with variations of the UR farction by $\pm 10 \%$ (vertical error bars) 
Considering the urgency to shift from a fossil fuel based energy system to renewables, the untapped waste wood resources could be a viable bioenergy feedstock. To evaluate the emission reduction potential of each examined waste wood option, each emission profile was compared to different fossil fuels and landfill gas with energy recovery that reflect best the current UK energy system at the appropriate scale. The single point markers in Figure 3 show the typical emission intensity of the fossil fuel, landfill gas and incineration references on an equivalent lifecycle basis. Figure 9 represents the relative emission reductions for the investigated energy options and sensitivities compared to the reference cases. deliver the largest emission reductions compared to the reference cases. These reductions vary slightly when applying the above presented sensitivities but overall emission reductions are still achieved. Grade A chips achieve the highest reductions in a range between $68 \%$ and $91 \%$. The highest relative emission reductions of about $91 \%$ are achieved by generating electricity from grade A chips compared to coal based electricity. Emission savings are lower when considering gas as reference energy option due to the lower emission intensity of natural gas, but $68 \%$ reductions are still achieved in the case CHP. to the additional energy required to produce pellets (grade $\mathrm{A}$ pellets) and to the formation of $\mathrm{N}_{2} \mathrm{O}$ during the combustion of panelboard (grade B chips). Although reductions of up to $83 \%$ for electricity from grade A pellets and $81 \%$ for electricity from grade B chips can be achieved. Overall grade B feedstocks provide emission reductions between $50 \%$ and $81 \%$ and grade A pellets between $48 \%$ and $83 \%$ for the different application options.

In case of the grade C-D (options), emission reductions are relatively low and in some cases exceed the emission of the energy reference significantly. Emission reductions from grade C-D are only achieved when large scale electricity from coal ( $28 \%$ reduction) or landfill gas with energy recovery ( $26 \%$ reduction) are replaced. In all other cases grade C-D based energy exceeds the emission of the reference options by $17 \%$ to $126 \%$. For the waste incineration reference case of energy from waste (EfW) it has to be kept in mind that the 

levels of treated waste wood.

Figure 9 Relative emissions reductions compared to fossil fuel reference in \%

352

The results show that grade $A$ and $B$ feedstocks achieve significant emission reductions with relatively small variations. Grade A pellets and grade B chips emission reductions are slightly less due to a higher processing energy penalty from pelletizing and for UR fraction related $\mathrm{N}_{2} \mathrm{O}$ formation respectively. The emissions from both feedstocks (grade A pellets and grade B chips) are relatively similar, which means that a feedstock with some degree of contamination can provide similar emission reductions as untreated wood pellets. The emission savings from grade C-D are relatively limited and only achieved when to electricity generation from coal and landfill gas. For all other options grade C-D feedstocks exceeds the emissions compared to the fossil fuel reference. In terms of decarbonising the energy sector UR containing waste woods therefore offer some potential when replacing coal and landfill gas and additionally this would reduce landfill and related emissions (Brown and Kearley, 2012; Defra, 2012a, b; Mitchell and Stevens, 2008). analysis showed that variations in fuel use do not have a significant emission impact, consistent with findings of comparable research (Mitchell and Stevens, 2008). However, only regional supply chains and relatively short distances have been considered. Other research showed that bioenergy operators consider longer distance transport of feedstocks not feasible as this would increase the cost (Forsberg, 2000; Goh and Junginger, 2013; Röder, 2016) and the emission burden (Bows-Larkin et al., 2015; Röder et al., 2015; Walsh and Bows, 2012). The UK is a major global importer of woody biomass and the largest importer of wood pellet (FAO, 2016); at

371 the same time large amounts of organic residues and wastes are currently not used or exported (Defra, 2012b;

372 Greenhalf and Brown, 2012). More local and regional bioenergy and waste management supply chains could therefore potentially improve the emission savings (Welfle et al., 2014). 

here presented analysis showed that indoor processing with electricity-powered equipment can reduce the emissions of all investigated options. In particular, for grade A chips indoor processing offered the highest mitigation potential of the evaluated sensitivities. Considering renewable energy support schemes with set emission thresholds, a shift to indoor electricity-powered processing could offer benefits in terms of achieving these targets and providing further reductions. With the outlook of a continuous reduction of the carbon intensity of the electricity mix, emission benefits from indoor processing would increase even further. Moreover the waste wood processing industry has to comply to various environmental regulations (WRAP, 2012). Indoor processing would provide a better control of health, safety and environmental issues such as dust, fines and noise.

There is a large body of literature showing that pelletizing reduces the emission savings from bioenergy feedstocks and the rationales and impacts for the use of pellets have been discussed widely (Adams et al., 2015; Alakoski et al., 2016; Cocchi et al., 2011; Lamers et al., 2012; Sikkema et al., 2011). Nonetheless, so far previous research considers a single numbers for the electricity required for the pelleting process. The here presented evaluation showed there is quite some variation in the data leading to possible changes in the total supply chain emissions by up to $23 \%$ higher and up to $27 \%$ lower emissions compared to the baseline. This is quite significant when considering the mitigation potential of pellet feedstocks. Higher transparency in reporting of the processing fuel demand and optimising fuel use could reduce this uncertainty and benefit the understanding of the emission reduction potential of pellet feedstocks. which also causes the strongest variations to the emission profile of these options. It is unlikely that grade $B, C$ and D waste wood always have the same UR fraction due to inconsistencies in the waste mix and the sensitivity analysis showed how significantly this could vary the actual emission. Moreover, up-to-date knowledge about $\mathrm{N}_{2} \mathrm{O}$ formation during combustion is limited and therefore another source of high uncertainty. The assumed value for this research was the best available number and taken from the BEAT2 V2.1 model which is widely used but also criticised by many experts for being highly uncertain. Selective catalytic reduction and high temperatures during incineration could potentially reduce the formation of $\mathrm{NO}_{\mathrm{x}}$ 

risk of the release of $\mathrm{N}_{2} \mathrm{O}$ from the catalytic converters (Defra, 2013; Eric and David, 2014; Harris et al., 2015; Møller et al., 2011; Nixon et al., 2013; Van Caneghem et al., 2016). Reducing and increasing the formation rate in the sensitivity analysis showed the related variations. It also showed that $\mathrm{N}_{2} \mathrm{O}$ formation from UR during energy conversion is a major concern even with lower UR fractions and low $\mathrm{N}_{2} \mathrm{O}$ formation rates. To achieve higher emission reductions from grade $B, C$ and $D$ feedstock a pre-treatment to reduce or even remove the UR could be a way to improve the emission profile of theses feedstocks. Resins are soluble in water and therefore washing could be a valid and low cost pre-treatment to remove resins (Kaczala et al., 2010). Research by others has shown that there are not only environmental benefits but that washing of the feedstock also improves the properties for combustion (Gudka et al., 2016).

Washing might not remove all UR but the calculation showed that a reduction of UR fraction could lead to significant emission reductions and improve the climate change mitigation potential of these feedstocks. If the feedstock is pre-treated and UR removed, not just the potential of $\mathrm{N}_{2} \mathrm{O}$ formation during energy conversion is significantly reduced but these feedstocks could then also be used in more efficient facilities, further reducing the overall emissions. However, there is a need to better understand the release and conversion of $\mathrm{N}_{2} \mathrm{O}$ under different conditions. In case of grade D waste wood, UR could be removed through washing but other contaminations such as melamine, arsenic, chromium, copper, halogens, halides or volatile organic compounds would still be an environmental issue (Defra, 2012a; Jambeck et al., 2007; Mercer and Frostick, 2012, 2014).

Thorough waste wood separation practices would help to efficiently pre-treat UR containing material and support an optimised use of the different feedstocks, possibly not just for energy generation but also for other cascading uses which are discussed by others (Defra, 2012a; Mitchell and Stevens, 2008).

Overall the results show that waste wood-based energy in particular from grade B feedstocks can provide high emission reductions throughout all analysed applications and compared reference scenarios. Emission reductions from grade B can be maximised when generating large-scale electricity and commercial scale heat, with emission levels similar to untreated wood pellets. From this, it appears viable to use grade B feedstock for large-scale applications compliant with WID replacing untreated feedstocks in particular pelletized feedstocks, 
while using untreated feedstocks preferably in small-scale applications. Emission reductions from grade C-D feedstocks are limited but still, over $25 \%$ emission reductions can be achieve when generating large-scale electricity replacing coal and landfill gas with energy recovery. As discussed in detail by Thornley et. al (Thornley et al., 2015), optimising feedstock use and maximising emission reductions of various feedstockapplication systems can support the urgent need to reduce emissions from the energy sector in a timely manner. It is important to consider that biogenic carbon was not included in the analysis. Current accounting frameworks consider woody biomass as carbon neutral. This can be misleading as in case of timber and wood products the point in time of carbon sequestration and carbon release, e.g., when generating energy from waste wood these units of $\mathrm{CO} 2$ are not compensated for by contemporaneous sequestration (Röder and Thornley, 2016). Especially within a cumulative carbon budget it is important to assess when emissions are release and when sequestered. Currently no standardised approach exists integrating a system's carbon balance and lifecycle emissions. However, the LCA approach provides the GHG performance of each specific lifecycle step, allowing identifying the key impacts and the emission variability and comparing emissions of different systems at a specific point in time.

The objective of this research was to evaluate the climate change impacts and related emission uncertainties of waste wood based energy. Grades A, B and C-D waste woods with CHP, electricity generation and heat generation have been investigated. The results show that the emissions from energy generated from different waste wood grades vary largely. While grade A waste wood achieves reductions of up to $91 \%$ compared to the

447 fossil fuel reference cases, emission levels from grade B feedstocks are similar to untreated waste wood pellets with savings up to $81 \%$ and emissions from grades C-D can exceed the reference cases in some options by up to $135 \%$ and only achieve limited emission reductions when replacing highly carbon intense energies. However the reference cases were related to the energy system and a comparison to waste management alternatives could present a different perspective. The evaluation of untreated waste wood showed clearly that bioenergy can contribute significantly to reducing emissions. It also showed that feedstocks with a low level of contamination achieve significant emission reductions similar to untreated waste wood pellets. To use higher 
contaminated feedstocks more sustainably pre-treatment to remove some of the emission causing

components including UR would be required.

It should be noted that one of the most significant drivers in determining the scope of systems evaluated in

this study is the legislative framework determining how waste wood is managed and disposed of. The classification of (often physically and chemically very similar) material can significantly impact on the resulting environmental impact and achievable greenhouse gas reductions. Where pre-treatment changes these characteristics or where compositional analysis shows absence of key contaminants it may be appropriate to reconsider the classification of waste based solely on its origin rather than its properties and associated potential to cause harm.

463

Acknowledgements

This paper is a contribution to the SUPERGEN Bioenergy Hub funded by the Engineering and Physical Sciences Research Council (EPSRC); Grant Ref: EP/J017302/1. The authors want to thank George Stammers for sharing his knowledge on waste wood and bioenergy systems. They also want to thank Dr Andrew Welfle for reviewing the assessment and for his feedback on the work.

Adams, P.W.R., Shirley, J.E.J., McManus, M.C., 2015. Comparative cradle-to-gate life cycle assessment of wood pellet production with torrefaction. Applied Energy 138, 367-380 http://dx.doi.org/10.1016/i.apenergy.2014.11.002. Alakoski, E., Jämsén, M., Agar, D., Tampio, E., Wihersaari, M., 2016. From wood pellets to wood chips, risks of degradation and emissions from the storage of woody biomass - A short review. Renewable and Sustainable Energy Reviews 54, 376-383 http://dx.doi.org/10.1016/i.rser.2015.10.021. Bows-Larkin, A., Anderson, K., Mander, S., Traut, M., Walsh, C., 2015. Shipping charts a high carbon course. Nature Clim. Change 5, 293-295 10.1038/nclimate2532. Brown, M., Kearley, V., 2012. Role of wood waste as source of biomass fuel in the UK. Energy Materials: Materials Science and Engineering for Energy Systems Volume 4, 162-165(164) BSI. Environmental management - Life cycle assessment - Principles and framework. Brussels. Standard, B.; 2006a; p. 32. BS EN ISO 14040:2006. 
BSI. Environmental management - Life cycle assessment - Requirements and guidelines. Brussels. Standard, B.; 2006b; p. 58. BS EN ISO 14044:2006. Cocchi, M., Nikolaisen, L., Goh, C.S., Junginger, M., Henimo, J., Bradley, D., Hess, R., Jacobson, J., Ovard, L., Thran, D., Hennig, C., Deutmeyer, M., Schouwenberg, P.P., Marchal, D. Global Wood Pellet Industry Market and Trade Study. Trade, I.B.T.S.B.; 2011; p. 190 from international freight transport. Journal of Environmental Economics and Management 65, 153 173 http://dx.doi.org/10.1016/i.jeem.2012.06.002.

Damen, K., Faaij, A.P.C., 2006. A Greenhouse Gas Balance of two Existing International Biomass Import Chains. Mitig Adapt Strateg Glob Change 11, 1023-1050 http://dx.doi.org/10.1007/s11027006-9032-y.

Defra. Waste Wood as a Biomass Fuel. London. Defra; 2008; p. 42

Defra. Biomass Environmental Assessment Tool, Version 2.1 (BEAT2). London. Prepared by AEA Group plc and North Energy Associates Ltd for Department for Environment Food and Rural Affairs and the Environment Agency. 2010

Defra. The waste incineration directive. London. Defra; 2011; p. 96

Defra. An assessment of the environmental impact of management options for waste wood. London. Defra; 2012a; p. 22. WR1209.

Defra. Wood waste: A short review of recent research. London. Defra; 2012b; p. 29

Defra. Incineration of Municipal Solid Waste. 2013. PB13889.

Defra. 2016. Greenhouse Gas Conversion Factor Repository.

https://www.gov.uk/government/publications/greenhouse-gas-reporting-conversion-factors-2015 (accessed 08.02.2017).

Delgado, O., Lutsey, N. Advanced tractor-trailer efficiency technology potential in the 2020-2030 timeframe. Washington. ICCT; 2015; p. 66

DfT. 2014. Transport energy and environment statistics. Fuel Consumption (ENV01). https://www.gov.uk/government/statistical-data-sets/env01-fuel-consumption (accessed 08.02.2017).

EA. Pollution inventory reporting - combustion activities guidance note. Bristol. Agency, E.; 2013; p. 22

Ecoinvent. 2016. Swiss Centre for Life Cycle Inventories. http://www.ecoinvent.org/home/ (accessed 10.02.2017).

Edo, M., Björn, E., Persson, P.-E., Jansson, S., 2016. Assessment of chemical and material contamination in waste wood fuels - A case study ranging over nine years. Waste Management 49, 311-319 http://dx.doi.org/10.1016/j.wasman.2015.11.048.

EEA. 2013. Specific CO2 emissions per tonne-km and per mode of transport in Europe, 1995-2011. http://www.eea.europa.eu/data-and-maps/figures/specific-co2-emissions-per-tonne-2 (accessed 10.02.2017).

Enestam, S., Backman, R., Mäkelä, K., Hupa, M., 2013. Evaluation of the condensation behavior of lead and zinc in BFB combustion of recovered waste wood. Fuel Processing Technology 105, 161-169 http://dx.doi.org/10.1016/i.fuproc.2011.09.002.

Eric, A.D., David, K., 2014. Inventories and scenarios of nitrous oxide emissions. Environmental Research Letters 9, 105012

EUBIA. 2016. Biomass pelleting - Economics, applications and standards. http://www.eubia.org/index.php/about-biomass/biomass-pelleting/economics-applications-andstandards (accessed 10.02.2017).

Fantozzi, F., Buratti, C., 2010. Life cycle assessment of biomass chains: Wood pellet from short rotation coppice using data measured on a real plant. Biomass and Bioenergy 34, 1796-1804 http://dx.doi.org/10.1016/i.biombioe.2010.07.011. FAO. 2016. Forest statistics. http://www.fao.org/forestry/statistics/80938@180724/en/ (accessed 10.02.2017). 
536 Forsberg, G., 2000. Biomass energy transport: Analysis of bioenergy transport chains using life cycle 537 inventory method. Biomass and Bioenergy 19, 17-30 http://dx.doi.org/10.1016/S0961-

\section{9534(00)00020-9.}

539 Goh, C.S., Junginger, M. Low Cost, Long Distance Biomass Supply Chains. 40, I.B.T.; 2013; p. 65

540 Gomez-Barea, A., Nilsson, S., Vidal Barrero, F., Campoy, M., 2010. Devolatilization of wood and

541 wastes in fluidized bed. Fuel Processing Technology 91, 1624-1633

542 http://dx.doi.org/10.1016/i.fuproc.2010.06.011.

543 Gori, M., Bergfeldt, B., Reichelt, J., Sirini, P., 2013. Effect of natural ageing on volume stability of

MSW and wood waste incineration residues. Waste Management 33, 850-857

http://dx.doi.org/10.1016/j.wasman.2012.12.005.

Greenhalf, M., Brown, M. Business case for wood waste collection hubs. Banbury, Oxon. WRAP; 2012; p. 42. EFI001-003.

Gudka, B., Jones, J.M., Lea-Langton, A.R., Williams, A., Saddawi, A., 2016. A review of the mitigation of deposition and emission problems during biomass combustion through washing pre-treatment. Journal of the Energy Institute 89, 159-171 http://dx.doi.org/10.1016/j.joei.2015.02.007.

Hamelinck, C.N., Suurs, R.A.A., Faaij, A.P.C., 2005. International bioenergy transport costs and energy balance. Biomass and Bioenergy 29, 114-134 http://dx.doi.org/10.1016/j.biombioe.2005.04.002.

Harris, E., Zeyer, K., Kegel, R., Müller, B., Emmenegger, L., Mohn, J., 2015. Nitrous oxide and methane emissions and nitrous oxide isotopic composition from waste incineration in Switzerland. Waste Management 35, 135-140 https://doi.org/10.1016/j.wasman.2014.10.016.

Hwang, I.-H., Kobayashi, J., Kawamoto, K., 2014. Characterization of products obtained from pyrolysis and steam gasification of wood waste, RDF, and RPF. Waste Management 34, 402-410 http://dx.doi.org/10.1016/j.wasman.2013.10.009.

ICCT. Quantifying the impact of real-world driving on total $\mathrm{CO} 2$ emissions from UK cars and vans. Final report for The Committee on Climate Change. Cambridge. ICCT; 2015; p. 52 Jambeck, J., Weitz, K., Solo-Gabriele, H., Townsend, T., Thorneloe, S., 2007. CCA-Treated wood disposed in landfills and life-cycle trade-offs with waste-to-energy and MSW landfill disposal. Waste Management 27, S21-S28 http://dx.doi.org/10.1016/j.wasman.2007.02.011.

Jonker, J.G.G., Junginger, M., Faaij, A., 2013. Carbon payback period and carbon offset parity point of wood pellet production in the South-eastern United States. GCB Bioenergy 6, 371-389 http://dx.doi.org/10.1111/gcbb.12056.

Kaczala, F., Marques, M., Hogland, W., 2010. Biotreatability of wastewater generated during machinery washing in a wood-based industry: COD, formaldehyde and nitrogen removal. Bioresource Technology 101, 8975-8983 http://dx.doi.org/10.1016/j.biortech.2010.06.122. Khalfi, A., Trouvé, G., Delobel, R., Delfosse, L., 2000. Correlation of CO and PAH emissions during laboratory-scale incineration of wood waste furnitures. Journal of Analytical and Applied Pyrolysis 56, 243-262 http://dx.doi.org/10.1016/S0165-2370(00)00099-1.

Lamers, P., Junginger, M., Marchal, D., Schouwenberg, P.-P., Cocchi, M. Global wood chip trade for energy. 40, I.B.T.; 2012; p. 24

Lavric, E.D., Konnov, A.A., Ruyck, J.D., 2004. Dioxin levels in wood combustion-a review. Biomass and Bioenergy 26, 115-145 http://dx.doi.org/10.1016/S0961-9534(03)00104-1. Letsrecycle. Veolia reveals extent of waste wood sent to landfill. letsrecycle.com; 2015; p. 2 Liu, H., Chaney, J., Li, J., Sun, C., 2013. Control of NOx emissions of a domestic/small-scale biomass pellet boiler by air staging. Fuel 103, 792-798 http://dx.doi.org/10.1016/i.fuel.2012.10.028. McKechnie, J., Colombo, S., Chen, J., Mabee, W., MacLean, H.L., 2010. Forest Bioenergy or Forest Carbon? Assessing Trade-Offs in Greenhouse Gas Mitigation with Wood-Based Fuels. Environmental Science \& Technology 45, 789-795 http://dx.doi.org/10.1021/es1024004.

McManus, M.C., 2010. Life cycle impacts of waste wood biomass heating systems: A case study of three UK based systems. Energy 35, 4064-4070 http://dx.doi.org/10.1016/i.energy.2010.06.014. 
585 Mercer, T.G., Frostick, L.E., 2012. Leaching characteristics of CCA-treated wood waste: A UK study.

586 Science of The Total Environment 427-428, 165-174

$587 \quad$ http://dx.doi.org/10.1016/i.scitotenv.2012.04.008.

588 Mercer, T.G., Frostick, L.E., 2014. Evaluating the potential for environmental pollution from chromated copper arsenate (CCA)-treated wood waste: A new mass balance approach. Journal of Hazardous Materials 276, 10-18 http://dx.doi.org/10.1016/j.jhazmat.2014.05.006. Mitchell, A., Stevens, G. Life Cycle Assessment of Closed Loop MDF Recycling: Microrelease Trial Banbury, Oxon. WRAP; 2008; p. 50. Gnosys Report number: GR185.

Mitchell, E.J.S., Lea-Langton, A.R., Jones, J.M., Williams, A., Layden, P., Johnson, R., 2016. The impact of fuel properties on the emissions from the combustion of biomass and other solid fuels in a fixed bed domestic stove. Fuel Processing Technology 142, 115-123

http://dx.doi.org/10.1016/i.fuproc.2015.09.031.

Møller, J., Munk, B., Crillesen, K., Christensen, T.H., 2011. Life cycle assessment of selective noncatalytic reduction (SNCR) of nitrous oxides in a full-scale municipal solid waste incinerator. Waste Management 31, 1184-1193 https://doi.org/10.1016/j.wasman.2010.12.019.

Muncrief, B.S.a.R. Literature review: Real-world fuel consumption of heavy-duty vehicles in the United States, China, and the European Union. Washington. ICCT; 2015; p. 30

Muncrief, R., Sharp, B. Overview of the heavy-duty vehicle market and $\mathrm{CO} 2$ emissions in the European Union. ICCT; 2015; p. 14

Nixon, J.D., Wright, D.G., Dey, P.K., Ghosh, S.K., Davies, P.A., 2013. A comparative assessment of waste incinerators in the UK. Waste Management 33, 2234-2244

https://doi.org/10.1016/i.wasman.2013.08.001.

Pöyry. Pöyry Forest Industry Consulting Ltd and Oxford Economics Ltd. Wood Waste Market in the UK. Banbury, Oxon. WRAP; 2009; p. 37. MKN022.

PRé. SimaPro Database Manual. Methods Library. PRé; 2016; p. 63

Röder, M., 2016. More than food or fuel. Stakeholder perceptions of anaerobic digestion and land use; a case study from the United Kingdom. Energy Policy 97, 73-81

http://dx.doi.org/10.1016/i.enpol.2016.07.003.

Röder, M., Thornley, P., 2016. Bioenergy as climate change mitigation option within a $2^{\circ} \mathrm{C}$ targetuncertainties and temporal challenges of bioenergy systems. Energy, Sustainability and Society 6, 1-7 10.1186/s13705-016-0070-3.

Röder, M., Whittaker, C., Thornley, P., 2015. How certain are greenhouse gas reductions from bioenergy? Life cycle assessment and uncertainty analysis of wood pellet-to-electricity supply chains from forest residues. Biomass and Bioenergy 79, 50-63 10.1016/j.biombioe.2015.03.030.

Sheth, P.N., Babu, B.V., 2010. Production of hydrogen energy through biomass (waste wood) gasification. International Journal of Hydrogen Energy 35, 10803-10810

http://dx.doi.org/10.1016/j.ijhydene.2010.03.009.

Sikkema, R., Steiner, M., Junginger, M., Hiegl, W., Hansen, M.T., Faaij, A., 2011. The European wood pellet markets: current status and prospects for 2020. Biofuels, Bioproducts and Biorefining 5, 250278 10.1002/bbb. 277.

Skoglund, N., Bäfver, L., Fahlström, J., Holmén, E., Renström, C., 2016. Fuel design in co-combustion of demolition wood chips and municipal sewage sludge. Fuel Processing Technology 141, Part 2, 196201 http://dx.doi.org/10.1016/j.fuproc.2015.08.037.

Thek, G., Obernberger, I., 2004. Wood pellet production costs under Austrian and in comparison to Swedish framework conditions. Biomass and Bioenergy 27, 671-693

http://dx.doi.org/10.1016/i.biombioe.2003.07.007.

Thornley, P., Gilbert, P., Shackley, S., Hammond, J., 2015. Maximizing the greenhouse gas reductions from biomass: The role of life cycle assessment. Biomass and Bioenergy 81, 35-43 http://dx.doi.org/10.1016/i.biombioe.2015.05.002. 
Thornley, P., Upham, P., Huang, Y., Rezvani, S., Brammer, J., Rogers, J., 2009. Integrated assessment of bioelectricity technology options. Energy Policy 37, 890-903

636 http://dx.doi.org/10.1016/i.enpol.2008.10.032.

637 Tolvik. 2011 Briefing Report: The UK Waste Wood Market Ltd, T.C.; 2011; p. 31

638 Van Caneghem, J., De Greef, J., Block, C., Vandecasteele, C., 2016. NOx reduction in waste

639 incinerators by selective catalytic reduction (SCR) instead of selective non catalytic reduction (SNCR)

640 compared from a life cycle perspective: a case study. Journal of Cleaner Production 112, 4452-4460

641 https://doi.org/10.1016/i.jclepro.2015.08.068.

642 Vanneste, J., Van Gerven, T., Vander Putten, E., Van der Bruggen, B., Helsen, L., 2011. Energetic

643 valorization of wood waste: Estimation of the reduction in $\mathrm{CO} 2$ emissions. Science of The Total

644 Environment 409, 3595-3602 http://dx.doi.org/10.1016/i.scitotenv.2011.04.059.

645 Volvo. 2015. The driving force. http://www.volvotrucks.com/trucks/uk-market/en-

$646 \mathrm{gb} /$ trucks/our trucks/Pages/energy efficiency.aspx (accessed 10.02.2017).

647 VTT. 2013. LIPASTO traffic emissions. http://www.lipasto.vtt.fi/indexe.htm (accessed 10.02.2017).

648 Walsh, C., Bows, A., 2012. Size matters: Exploring the importance of vessel characteristics to inform

649 estimates of shipping emissions. Applied Energy 98, 128-137 10.1016/j.apenergy.2012.03.015.

650 Welfle, A., Gilbert, P., Thornley, P., 2014. Securing a bioenergy future without imports. Energy Policy

651 68, 1-14 http://dx.doi.org/10.1016/j.enpol.2013.11.079.

652 Wilen, C., Moilanen, A., Hokkinen, J., Jokiniemi, J. Fine particle emissions of waste inceneration. IEA

653 Bioenergy Task 36, V.; 2007; p. 44

654 WPIF. Panel Guide, Annex A. Grantham. Federation, W.P.I.; 2014a; p. 7. V4.

655 WPIF. Panel Guide, Annex E. Grantham. Federation, W.P.I.; 2014b; p. 8. V4.

656 WRAP. Wood Waste Market Situation Report. WRAP; 2011; p. 12. April 2011.

657 WRAP. PAS 111:2012. Specification for the requirements and test methods for processing waste

658 wood. London. BSI; 2012; p. 40

659 Yorulmaz, S.Y., Atimtay, A.T., 2009. Investigation of combustion kinetics of treated and untreated

660 waste wood samples with thermogravimetric analysis. Fuel Processing Technology 90, 939-946

661 http://dx.doi.org/10.1016/i.fuproc.2009.02.010. 